\title{
The shape of a woman's life: Lady Anne Barnard's Memoir
}

\begin{abstract}
In her old age, Lady Anne Barnard revised the diaries and letters which remained from her life in Scolland, London, and at the Cape. She shaped part of these records into a six-volume Memoir and since a man's memoir would concentrate attention on his public life and achievements, she cast it into a shape which recalls that of the 'female' novel of the eighteenth century. She therefore presents her rejection of the lifestyle of her family, that of impoverished Scottish aristocrats, and her move to London, as a quest for a suitable marriage. This view of her life was not, however, entirely congenial to her: she had a strong sense of her achievements as an autonomous individual, rather than as the lesser partner in a marriage, and although the Memoir ends with her marriage, there is much evidence in it of her pride in having originated and achieved for herself a new lifestyle.
\end{abstract}

In 1822, when Lady Anne Barnard was seventy-two years old and living in London, she recorded that seven years previously she had given up her carriage and horses and had converted them, as she put it, into "transcribers ... portrait painters ... bookbinders"1 whom she could employ in the task which she had set for herself in her old age, the revision of diaries, letters and other documents into a memoir of her life. Transcribed by secretaries and illustrated with engraved

I This statement appears on an unnumbered page at the beginning of Volume I of Lady Anne Barnard's Memorr. 
portraits of people mentioned in the text, the Memoir ${ }^{2}$ which she produced in this way consists of six quarto volumes. Its very bulk makes a claim for significance, though the mixture of intentions and tones within it suggests that its author had several purposes in her narrative, rather than the single intention of self-portraiture.

A woman who decided to write the story of her life in the early nineteenth century had to be aware of a reluctance in her audience to receive her work as interesting, if it was entirely domestic, or legitimate, if it suggested that she had played a public role. When Lejeune (1989:3-30) writes of the "autobiographical pact", which implies an intention in the writer that the work be received, and a willingness in the envisaged reader to receive it, in a particular way, he is assuming that both writer and reader are agreed on the propriety of such a life story's being published. When, however, a woman of the early nineteenth century felt that her life story deserved to be recorded, but could not assume that the reading public would agree with her, she had several courses available to her. She need not publish; she might simply bequeath her diaries to her descendants in the hope that some of them might choose to read them. Alternatively, she might, like Lady Mary Wortley Montagu in the eighteenth century, settle for a tiny readership in her own lifetime and fragment her story into letters. There was another course which Lady Anne Barnard chose: she recast her diaries into the form of a memoir, (the term autobiography did not, according to the Oxford English Dictionary, become current until the 1840s) but forbade publication and restricted its circulation to a selected group - that of her extended family and their friends.

In Imagining a Self, Patricia Meyer Spacks (1975:82) claims in her discussion of women's published life stories in the eighteenth century that

2 Lady Annc Barnard's main bodies of writing, the publication of which she always forbad, were the Memoir, which is the subject of this essay, the Cape Journal, which she revised in the same period as the Memoir, and which cxists in three volumes, "Sea Journal to the Cape of Good Hope", "Residence at the Cape of Good Hope" and "Short Tour into the Interior Part of Africa". She was also a great Ictter-writer, and her correspondence with Henry Dundas, then the Minister for War and the Colonics, from the Cape of Good Hope, was preserved by him and has been edited by A. M. Lewin Robinson and published as The Letters of Anne Barnard to Henry Dundas (1973). The Cape Journals, also edited by A.M. Lewin Robinson, are to be published in the ncar future by the Van Riebeeck Socicty in Cape Town. The Memoir and the Cape Journals arc the property of the Earl of Crawford, and have been loaned by him to the National Library of Scotland. References to the Memoir within this essay are contained within brackets and consist of a volume number followed by a page number. 
Spiritual autobiography provided a respectable mode of expression for the regenerate female; actresses and women of dubious repute published their life stories as part of their more or less scandalous self-display ... In some ways, therefore, we might expect the most revealing female autobiographies of the century to emerge from collections of letters and diaries not avowedly intended for the public eye.

Lady Anne's Memoir stands midway between the published life story, itself constituting in the period a dangerous self-display in the case of a woman whose principal characteristic is not piety, and the collection not intended for the public eye. As a member of a very large family, with even larger numbers of friends and comnections, when she caused her Memoir to be recopied into the state in which it now exists (there are two copies of the whole) she must have anticipated her writing's being scrutinised by a large group of people. Letitia Pilkington and Charlotte Charke, two of the women whose life stories Spacks has considered, both emphasise that the calamities of their lives have forced them out of society (Spacks, 1975:73). They have, of course, famous fictional predecessors in Moll Flanders and Roxana: Defoe's fake memoirs exploit very completely the fascination of deviance. Lady Anne's intention in her Memoir is to show, not a societal disaster, but a successful social transition, and marriage, though hers will be an unusual one, must mark the kind of success which she achieves. Even less than deviance does she intend to represent piety and passivity; she is determined to show that she owes her achievements to her own efforts. Women's life-writing of the period does not offer her a suitable model.

Although she makes no claim to piety or to any other exemplary quality, Lady Anne has reasons for believing that her life has sufficient significance to warrant the modest degree of currency which she intends for it. Her achievements in Scotland and in England were, as the Memoir shows, varied and considerable, and she had travelled to the Cape of Good Hope (an unusual feat for a woman of her class in the period) and had spent five years there, for a considerable part of which she had been the official hostess of the British administration. Probably feeling that the account of her life at the Cape possessed a special kind of interest, akin to that of the traveller's account which was popular in the period ${ }^{3}$, she edited the diaries of her jounney to and residence at the Cape separately from the Memoir, and apart from commenting at the end of Volume 4 of the Memoir that "... it was there [in Africa] I spent the happiest years of my Life" (4.318) does not discuss the Cape within the Memoir.

3 I have discussed at some lenght the relationship between Lady Anne's writings from the Cape and John Barrow's Travels into the Interior of Southern Africa in "All the lighter parts: Lady Anne Bamard's letters from Cape Town" (Lenta, 1992:57-71). 
If the traveller's account offered Lady Anne a model which she could consult and modify for her revised Journal, the account of her youth and adult life before marriage, which is dealt with in Volumes 1-4 of the Memoir, required another model. Though she had taken a modest part in public life whilst living in London, her sense of her early life seems to have been that a pattern which would focus on political or public interactions, and which might suit the record of a man's life, was not for her. She seems to have known that she had constructed herself, through a course of action which at the time seemed a series of rejections rather than positive choices, as a new kind of woman, and that she had been a force for change in her ancient family. I shall argue that the pattern which offered itself to her for this interpretation of her life was that of the female novel, to which she makes several references in the Memoir, and which is clearly the shaping influence on her story up to her marriage at the end of Volume 4. I use the term female novel for that major strain of eighteenth century fiction, begun by Richardson with Pamela (1740), and continued by many minor writers, as well as by the major novelists Fanny Burney and Jane Austen. Pamela was an all-time best-seller which established that courtship, and the conflicts which it might involve between the female protagonist, her family and her lover, might well form the shaping theme for a novel. Richardson's masterpiece, Clarissa (1747), which deals with greater skill and seriousness than is present in Pamela with the problems of young women, is a strong influence, as I shall show, in Lady Anne's account of her youth. The later novelist, Fanny Burney, in whose first novel, Evelina (1778), the heroine has to cope with the middle-class London of tradespeople as well as aristocratic circles, gives Lady Anne a way of understanding and presenting her own experience in London, where, like Evelina, she lived without family to protect her.

The question of to what extent Lady Anne fictionalised her life and whether she took liberties with matters of fact cannot be answered at this late date with absolute certainty. She addresses, in her introduction to the Memoir, younger members of her own family, who will have known her in her old age, and will presumably have some possibility of verifying her story, through their access to other accounts of their family. The fact that her nephew drew on the Memoir for his family history, The lives of the Lindsays, ${ }^{4}$ (Crawford \& Balcarres, 1849) suggests that it was regarded as reliable in matters of fact. More interesting for my purposes are what might be called matters of attitude: Lady Anne persuades her readers to understand and sympathise with her in actions which many moralists in the period would have censured, but which the female novel had accustomed

4 Chapter XVII of The Lives of the Lindsays, or, a Memoir of the Houses of Lindsay and Balcarres, by the 25th Earl of Crawford and Balcarres, contains much quotation from the Memoir. 
readers to accept. The extent to which this type of novel was not only a symptom of growing female aspirations towards self-determination, but tended to legitimise such aspirations in its readers may be seen in Lady Anne's presentation of her life: what in her youth would have been seen ungrateful rebellion in a child, she is able to present as a legitimate search for a suitable lifestyle. A second question, as to why, since she used the tropes legitimised in fiction within her Memoir, she did not actually turn the material of her life into a novel, also arises. The answer is probably that she desired, and felt that she needed, the authority of the authentic life story.

To suggest that Lady Anne consciously sought a form for her Memoir and found it in the novel may be to undervalue the enormous influence of novels on women's perceptions of their lives. The truth may be that it was because of her reading of fiction that she was able to see her early life as possessing the pattern which the Memoir records. What is certain is the validity in Lady Anne's case of Eakin's (1985:5) claim that

... fictions and the fiction-making process are a central constituent of the truth of any life as it is lived, and of any art devoted to the presentation of that life ... autobiography ... expresses the play of the autobiographical act itself, in which the materials of the past are shaped by memory and imagination to serve the needs of present consciousness.

Since the Memoir has never been published, it may be useful to offer a brief synopsis of its contents. In Volumes 1, 2 and the first part of 3, Lady Anne tells the story of her childhood, adolescence and young adult life, offering an account of why and how she left her Scottish family to settle in London. The latter part of Volume 3 deals with the journey to the continent with Mrs. Fitzherbert, the beloved of the Prince of Wales, later George IV. In Volume 4, although she continues to mention Mrs. Fitzherbert and the Prince, other figures, especially William Windham and Henry Dundas, move from time to time close to herself at the centre of the narrative. A protracted period of search for direction comes to an end for Lady Anne when, at the end of this volume, she agrees to marry Andrew Barnard, twelve years younger than herself. The marriage occurs in 1793, and in 1796 Bamard is appointed Secretary of the Cape Colony, where he and Lady Anne arrive early in 1797. A break of five and a half years occurs at this point in the Memoir. In Volumes 5 and 6, especially after the death of Barnard, Lady Anne moves out of the centre of her narrative, and the focus is mainly on family news and contacts with important friends, especially the Royal family.

I have chosen in this essay to focus on Volumes 1-4, where Lady Anne uses the novel pattern to give unity and focus to her matter. I have omitted, because of the constraints of space, the visit to the continent with Mrs. Fitzherbert in Volume 3. 
This episode seems to belong to another genre, that of Sterne's Sentimental Journey (1768) (to which she makes reference), and seems to deserve a separate study.

The double title of the work, The History of the Family of St Aubin and the Memoirs of Louisa Melford, signals Lady Anne's reluctance to present it simply as the story of her own life. She also refers to it in her introduction as 'Tales of Other Times', and recollects her father's maxim that a person who leaves no trace of his mind behind him fails society and his maker (1.1). In the first twenty pages she offers a brief but lively history of the family before her own birth. Yet the claim that the whole is a history is not avoidance of overt self-display: it is a daring assertion that her own life, in which she moved from the impoverished and declining post-Jacobite Scottish aristocracy and re-established herself as a member of the new, British aristocracy, was an important chapter in the Lindsay family story. Nussbaum (1989:xii) has observed that

This historical period of eighteenth century England ... is a time when identity and character are in particular crisis, and autobiographical writing often sparks nonhegemonic concepts about the self as well as new hegemonies in formation.

The sense that roles related to class and gender have changed in her lifetime is certainly a part of Lady Anne's wish to record her experience. Her willingness to present herself as rejecting the role of daughter, which in her youth implied passivity and subjection, and as unable, in Scotland, to marry, suggest her awareness of what Nussbaum has called 'crisis': her rejections imply that she discerned, however vaguely, that new possibilities for women were available, though difficult of achievement.

Lady Anne mentions in her introduction that she regrets that she "ever gave Feigned names to Real characters - delicacy to contemporaries was my motive ... I have outlived almost the whole and caution ceases to be necessary ...". She is referring to the fact that she uses the pseudonym Louisa Melford for herself, calls her sister Margaret, Hortensia, and her family, the Lindsays, the St Aubins and so on.' She suggests nevertheless that the fictional names allow the Memoir to be read, by those who wish to do so, purely as a story. The idea that the element of family history may be ignored and the work nevertheless retain some of its interest is an admission that Lady Anne believes her experience to have general validity, and it is the first direct reference to the concept of fictional narrative within the work.

3. The real names of people, when they are known, have for the convenience of readers been used within this cssay 
In Volume 1, she adheres to what we may call the Clarissa tradition by conveying her rejection of the lifestyle which she has inherited as a series of refusals of marriages, some of them desired by her family, which would have fixed her in Scotland, and in the society into which she was bon. There is never a high degree of unity: there is a large variety of episodes, connected only by the idea that she must discover that she camnot marry appropriately in Scotland. The reader feels that she is being faithful to the experience of her life as well as shaping it in terms of her theme.

Close to the beginning is the story of her birth: in these early pages the historical purposes of the narrative are closely integrated with the biographical, and her belief that, born in 1750, five years after the Jacobite rebellion of 1745, she arrived at the end of an historical period, is made clear. She was the eldest child of the Earl of Balcarres, and the country people believed during Lady Balcarres's pregnancy that this child would restore the former glories of the family, and bring back the Stuart kings. She records with amusement the disappointment when the birth of a little girl dashed their hopes. The story of her birth, however, is not one of a child who disappointed her parents: as Lady Anne tells it, it is of an absurd, because anachronistic expectation. For the Lindsays of her generation, heroic feats were as inappropriate as Jacobite sympathies.

Lady Anne depicts her elderly father as gentle and loveable but belonging to the past, and unable to understand the new conditions in which his children must live. It is her severe, unsympathetic mother, always ready to punish her children in their youth and to distmst them in their early adult life, who is the representative eighteenth century parent. Lady Anne admits the likelihood that her mother believed that she was acting in the children's best interests, but her verdict is "Upon the whole however I must think that tenderness is best, for is it nothing to save the happiness of ten or fifteen years?" (1.27). She is clear that neither parent could provide her or her siblings with a role model.

The maintenance of themselves as aristocrats was only possible for the family if they remained at Balcarres, where without loss of face they could live very simply. When discussing her early life at Balcarres, Lady Anne says, "tho our prison was a chearful one, yet still it was a prison"(1.37). It was a prison from which the boys in the family would escape early, as the poverty which confined the girls would force their brothers out early to repair the family fortunes. For the girls, even marriage would be difficult: Lady Anne explains that the Act of Union which had deprived Edinburgh of its Parliament had tended to draw able and energetic young men to England; in a very real sense, the capital of Scotland was now London. Nevertheless, only by marriage, it appeared, could their lives be made bearable. She receives her first proposal when she is sixteen, and when telling her of it, her mother reminds her 
... you are not very young ... you are past sixteen ... you are not what can be called Handsome ... you have got a blemish too [a small scar from measles] ... six hundred pounds is all you have to trust to ...(1.53).

This first, grotesque suitor is representative of the plight in which the Lindsays and their like found themselves: he is old, a merchant, and "has frequently been deranged in his intellects" (1.54). To marry him would be to accept that her own class no longer offered its daughters viable opportunities, since the young women it produced had not the dowries which would allow impoverished heirs to marry them. It would also be an acceptance that she, as an individual, did not have the power to transform herself. The elderly woman, looking back, can see that she did, in fact, have the energy and self-love which allowed her to make her way out of a society in decline.

As first person narrator Lady Anne uses irony to distance herself from the sufferings of her early years: a typical example is her account of her own and her sister's humiliations at the hands of some older cousins, who

... took so much charge of everyone's affairs, and especially those of the young folks, whom they loved so much that they thought it was a pity we should not be perfect and lectured us from morning to night lowering our spirits to keep down our vanity, as they said, of which we had unfortunately only that species which mounts with the kindness of friends and sinks with their disapprobation (1.59).

When she is seventeen, and together with her sister Margaret, in the middle of a season in Edinburgh, their father dies at Balcarres, as gentle and merry as ever, still with an optimism about their futures to which they respond with love: "... have my girls left any lovers behind them?..."

"None to signify." (1.63)

Yet although it is clear that the young girl idealised her father, the elderly woman who writes takes a more complex view. The funeral, she says, was made additionally affecting by the great number of young children, the youngest being still in the arms of his nurse. Lady Balcarres, since the heir is sixteen and away at school, must assume responsibility for the whole family, on an income of $£ 350$ a year. Whilst Lady Anne can see from the vantage point of old age that her mother was struggling against poverty and resentment of burdens, which as a woman she had never been trained to bear, to do what was best for her daughters, she remembers the apparent reluctance to allow them to enjoy anything. When they are to go on a visit, for example,

... all was arranged for our benefit, but instead of giving herself the credit of having done so unasked, she made us buy the boon so dear that fatigued by 
the warfare we actually gave up the solicitation, thinking it wrong to press a place of pleasure to ourselves contrary to her convenience (1.79).

An atmosphere of intriguing adults and miserable, incompetent girls, who always find themselves to blame, is typical of the years between Lord Balcarres's death and Lady Anne's move, about five years later, to London. The accounts of her rejections of suitors in this period seem to be symptomatic, as they might be in a fiction, of the encounters which a girl of her class and period could expect, and a later readership enjoy. They vary in tone from the comic (Count Hesse-Cassel, whom she suspects of being a double dealer because he wears false side curls) to the regretful (the dissolute but charming Harry Egremont, an impoverished younger son with whom she thinks of eloping) and the contemptuous, this last being her reaction to an aristocratic suitor who is attracted at different times to both her and her sister. He confides to a friend "that he had actually been in love with both, but thought us too clever to make good Wives ... what a poor minded opinion, but I believe it is not an uncommon one" (1.101). It is difficult to decide whether Lady Anne's comment is intentionally suggesting an interpretation of her difficulty in marrying suitably, but her comment "These Memoirs ... 1 speak it with shame ... are becoming a Mere Novel I see" (1.143-4), suggests an awareness that she is using a fictional pattern at this stage of her life-story.

Though the tone of the narrative is almost always that of the mature woman, measured and self-aware, there is far greater variety in the dialogue, even when the same speaker is being quoted. Lady Balcarres, for example, says to Anne on one occasion, "Monster ... I blush for you and your Subterfuges ... go to your room ... get out of my sight this moment and learn to conduct yourself without double dealing" (1.93). On another occasion she abandons melodrama and reproaches her daughters in mundane tones, telling them that if they do not soon marry, "goods which stick so long on the market plainly proved themselves to be unsaleable" (1.146). It is difficult not to feel that the melodramatic speech is influenced by the author's reading, and the coarse reproach by her memories.

In order to escape from Balcarres, Lady Margaret makes a disastrous marriage to Alexander Fordyce, a rich merchant who lives in London and therefore offers her escape, and who, to marry a beautiful girl of high rank, is willing to overlook her poverty. The principal incident of the period between Margaret's marriage and Lady Anne's own departure for London is the Swinton affair, perhaps the most reminiscent of all of Clarissa. Swinton is the friend and contemporary of her Dalrymple uncles, a man who is presumed very rich. He is most unattractive, having lost a hand and an eye. When he falls in love with Anne, pressure is brought on her to marry him out of 'gratitude', the implication being that a man who feels so much for a woman places her under an obligation to compensate him for his sufferings by marrying him. After much family blackmail, she decides to 
marry him and hopes that as he is a rich man, she will be allowed to visit her sister Margaret in London every few years. Swinton reveals that he has no intention of indulging her wishes, that she will be required to pay for the short period when his love for her gave her power over him by a life of subjection to his wishes. It emerges that his money is unwisely invested and he refuses to take advice offered him by Lady Balcarres which might make him into an acceptable parti for Anne. The whole incident is, like the Solmes incident in Clarissa $a^{6}$, a demonstration of the nightmare quality of eighteenth century family power struggles. Lady Anne fears to quarrel with the man with whom she may have to live, and who has already delivered himself of a sinister warning:

"Take care Lady Louisa ... take care common prudence should prevent you from giving such impressions ... they may recur when..." he stopped and sigh'd; ..."this looks too much like the desire of dominion over me," said he to himself ..."too much like making a Point"(1.231).

When the conflict is at its worst, a letter from Lady Margaret arrives: it is rendered by Lady Anne as "... come to my sisterly bosom and repose all thy griefs with me" (1.247). Apart from a few remarks about small amounts of money inherited from relatives, Lady Anne gives no account how she obtained the means and the permission to visit London.

In Volume 2, when she is in London with her sister and struggling towards financial independence and social acceptance, though Richardson is not absent, the stronger influence is probably Fanny Burney's Evelina. Both writers, but especially the latter, use the stagey and rhetorical speech which Lady Anne at times imitates in the dialogue of some of her upper class characters, and the often comic tradesmen's parlance which she uses when presenting lower class characters. She has already reminded her readers of the resemblance, and the difference, between her own life and novels by comparing herself to Harriet Byron, the heroine of Richardson's last novel, when she loses her friends at a masquerade: she longed "[t]o be rescued by a Sir Charles Grandison, but without the $\mathfrak{2 0 , 0 0 0}$ of the fair Harriet, I feared there was no chance of such an event" (2.39). When she describes Lady Margaret's letter to her husband, assuring him that she is coping with bankruptcy, the attempts at a primitive realism evoke those of Richardson's Pamela: she claims that having accidentally had sight of it, "I hastily seized the Pen and Ink ..."(2.58). Her sister's letter, as she offers it, reads as follows:

I would fain make you smile by painting to you the otherwise timorous Hortensia armed at all points fighting most valiantly against the foe 
misfortune and getting the better of him too by the sole armour of content and the hope of better days! ... (2.57).

The transparency of the literary strategem belongs to Richardson, the highflown rhetoric to Burney.

Lady Anne presents Fordyce as a deliberately eccentric, coarse bore, who enjoys a tyranny of caprice over his wife because it marks his ownership of her. The young women nevertheless enjoy themselves together: after "the black broth of Sparta (for I dare not say the sheeps heads of Scotland) seclusion and correction ... every little pleasure was a joy" (2.8).

Lady Anne's story in these years is one of surface acceptance of the notion that she can only find her place in the world by marrying. She refers to the difficulties of finding a suitable husband: "tho' 1 pleased $I$ had nothing for my Lovers to pay their debts with, or to appropriate to younger children ..." (2.206). But the traditional matter of the female novel is under strain as she makes discoveries about her own possibilities, though the question of whom she will marry is ostensibly the unifying subject. She records her pleasure in furnishing her own house: her talents as an artist were considerable, as her surviving work shows, and she seems, until her marriage, to have supported herself at least partly by decorating and furnishing houses in London, which she would then re-let. The Lindsay family at this stage was somewhat resentful of her growing independence and she records that she and Margaret were called by the rest 'the London ladies'. She writes that she wished her brothers to act for her in financial matters, but they could never come when they were wanted. She records that she herself learnt the hard way to do her own financial business: she refused, for example, records of her friend Williamson's investments on her behalf, so that when he died, she could recover very little: she hopes that her young readers will act differently. This very hope is an indication that she has worked through the paradoxes which confronted Richardson's Clarissa, who could not act competently in worldly affairs despite high intelligence, because to do so was morally wrong for women, and forced them beyond the limits within which they ought to live.

Several merchants propose to her, including her financial advisor, Williamson, who gradually, with advice about investments and action on their behalf, helps the two sisters to independence. She is sometimes regretful that she cannot accept such suitors, but always firm in her refusals. A dissolute aristocrat, Lord Wentworth, on the other hand, does attract her strongly for a while, even though lie is a gamester, drinks too much and is entangled with the ex-governess of his sisters. Though he is willing to borrow money from Lady Anne, she is not rich enough for him to marry her. The question of why she herself is attracted to a self-indulgent, dissolute man is interesting, but it is not answered for her readers, 
nor perhaps at this stage in her life was she herself sure about what role she wished to play in marriage. She relates a telling anecdote about a husband of her acquaintance, who says to his wife "... why should we consult you? Are we not your Emperors?" (2.248). It is evident that Lady Anne has learnt, in Scotland and in London, that her own marriage must not be of this kind.

The question must arise at this stage why Lady Anne did not abandon the literary convention of the comic novel which assumed that a woman's life culminated in marriage: why did she not recognise in her writing that her own achievement of maturity would be signalised in another way? The answer seems to be that no other form appeared more appropriate, and that although she did not see her own marriage in the way that marriage usually appears in the fiction of the period, as the beginning of a woman's adult life, she did believe that it had been a social necessity in her life. The discoveries of Volume 4, that she cannot have social power, or, without a husband, retain popularity and influence into her middle age, function as a chastening recognition that the 'female' novel, which, if comic, ends with the marriage of the heroine, and if tragic, with her death, contains a social truth for women. Although she is unwilling to present herself as receiving the scope she deserved through marriage, as for example Anne Elliot, in Persuasion, does, she records her perception that marriage is a necessary part of women's lives.

Gradually her marital prospects narrow themselves to two: Henry Dundas, the indispensable political associate of Pitt, then Prime Minister, and William Windham, whom she calls "Apollo Belvedere bent by illness" (4.80). Dundas is a friend from Edinburgh days; divorced and living for most of the year in London, he becomes an habitué of Lady Anne's house. Although she admires his brilliance and force, he does not attract her: she says of him "all was sullied and spoiled to us in his company by the coarseness and want of delicacy in his manners ..."(4.92). Dundas becomes indebted to Lady Anne when she uses her personal friendship with the Prince of Wales to secure a reconciliation between him and his father, George III, which appears to be effected by Dundas's good offices. On this occasion too she learns something: though privately grateful, Dundas will not admit publically that he owes anything to her. Women must be invisible in public affairs, except as the wives of statesmen.

Meanwhile she is strongly attracted by Windham, who is well known for his indecisiveness - 'Weathercock Windham' to his friends. He frequents her house, arranges to meet her on a country holiday, then arrives just too late at all their meeting places; on one occasion, he is about to propose and is interrupted by a servant with coals - "Oh what an Escape" [he cries] (4.97). But although she gives many instances of the perversity of his nature, Lady Anne prefers to reveal the confusion of his feelings through incident rather than to analyse why he is ambivalent about herself: he is both attracted and repelled by her strength. She 
herself cannot refrain from buying a house in Grosvenor Square because "it had a squint view of [Windham's] door" (4.162).

It is becoming clear that Dundas will soon wish to marry again: he invites Lady Anne to a dreadful dinner party where she meets his adult children. She remarks on the 'hostile eyes' upon her: "After a heavy evening I went home, my spirits fatigued by the day, and my ears grated with the Scotch dialect in all its purity, to which I had not been lately accustomed" (4.181). This is the atmosphere of the censorious and authoritarian aristocrats and gentry who frequented Edinburgh in her youth, and from whom she had been so happy to escape. Dundas himself, though Lady Anne admires him in many respects, is always, and significantly, even in his tender moments, given a strong Scottish accent. He is, however, an excellent match, not only financially, but because as a Minister of the Crown, second only to Pitt, he can give her the scope which she desires.

She goes at this point to Paris, where Windham is staying, and where he treats her abominably, but makes her aware that it is the strength of his attachment to her, as well as his resentment of it which produces his strange behaviour: "I was birds-lime - (it was not said in compliment) there was no getting away from me" (4.220). Finally, and in great pain, she breaks with him. When she returns to London, Dundas is unexpectedly removed from the list of possibles when he proposes to, and is accepted by, Lady Jane, the daughter of the rich Earl of Hopetoun. The concept of narrative revenge seems relevant here: ${ }^{7}$ Lady Anne seems to be defining Lady Jane as the antithesis of herself:

A gentle sad greyness pervaded her form, her dress, her manners, her mind ... a wife of this Hue which subdued with its respectable dullness the energy of everyone that approached her, was so totally inapplicable to [Dundas] that there was no accounting for the proposal but by the two additional Bottles of Claret which had given to him the Spirit she wanted (4.272).

It is impossible within the compass of an essay to do justice to the variety of life rendered within Lady Anne's writing, the pride and poverty of Edinburgh, the sinister chaos of post-revolutionary Paris, the many-layered liveliness of London. A few pages from the account of Dundas's marriage comes her decision to marry Andrew Barnard, a mere thirty-one to her forty-three, an ex-soldier invalided out, and in financial trouble. Barnard, she believes, truly loves her, though the reasons why he can marry her are that she can support them both, modestly, and it is

7 I owe this idea (used by him in the discussion of novels: in a memoir it is rather a different matter) to Professor John Jordan, of the University of La Cruz. It refers to a narrator's pleasure in giving a discreditable account of one who has injured her. 
likely that her friends can find him a public appointment. In her proposal scene, he asks on his knees if there is a chance for him, and she answers:

"I will throw aside all my Systems ... I will stand the world's smile ... Infinitely too old for you ... Infinitely too poor for you ... perhaps not wholely suited to you ... perhaps at present not happy ... but if I can make you happier than you are I will try to do so" (4.279-280).

The calm optimism of the passage produces a strong sense of closure. Barnard has already appeared in the narrative, though he has been a minor figure until this point, but the meaning of Lady Anne's acceptance of him is clear: she has accepted that a Windham will not marry the woman she has become, and that she cannot bring herself to marry a Dundas. If she remains unmarried, and increasingly unmarriageable, she must accept a marginal role in the world which she always admits she greatly enjoys. Marriage to Barnard will allow her to remain original and creative - will indeed force her to exercise in their joint interests both these traits. Nussbaum has commented that

[p]atriarchy, though pervasive, is unevenly distributed across class lines, and the interconnections of class with patriarchy are particularly instructive and contestatory in eighteenth century biography (1989:xviii).

Undoubtedly this is so: Lady Anne's early nineteenth-century record of her life in the eighteenth century shows that the scope which she enjoyed occurred in a temporary gap in the patriarchal structures of her own family, partly because of her father's death as she reached adulthood, but more because the patterns of life in the Scottish aristocracy were changing. Her route to status and security was particular to herself, and dependent on her talents and strength of character. Though she was able to present it in a form borrowed from the novel, and at the same time to claim for it the status of a history, she could not avoid revealing that it was form rather than ideology she was borrowing, and that her interest was in her own achievement, rather than in the history of her generation of Lindsays.

\section{Bibliography}

Barrow, John. 1802-1806. Travels into the Interior of Southern Africa. 2 vols London : Cadell \& Davies.

Burney, Frances. 1970 (1778). Evelina. London : Oxford University Press.

Crawford \& Balcarres, 25th Earl of. 1849. The Lives of the Lindsays, or, a Memoir of the Houses of Crawford and Balcarres. London : John Murray.

Defoe, Daniel. 1954 (1722). Moll Flanders London : The Folio Society

Defoe, Daniel. 1969 (1724). Roxana: The Fortunate Mistress. London : Oxford University Press.

Eakin, Paul John. 1985. Fictions in Autobiography: Studies in the Art of Self-Invention. Princeton : Princeton UP. 
Lejeune, Philippe. 1989. On Autobiography. In Eakin, John Paul (ed.). Fictions in Autobiography: Studies in the Art of Self-Invention. Minneapolis : University of Minnesota Press. pp. 3-30.

Lenta, Margaret. 1992. All the Lighter Parts: Lady Anne Barnard's Letters from Cape Town. Ariel, 22(2):57-71.

Montagu, Lady Mary Wortley. 1967. The Complete Letters of Lady Mary Wortley Montagu. Ed. by Halsband, Robert. Oxford : Clarendon Press

Nussbaum, Felicity A. 1989. The Autobiographical Subject: Gender and Ideology in Eighteenth Century England. Baltimore : Johns Hopkins Press. pxii.

Richardson, Samuel. 1972 (1753-4). Sir Charles Grandison. London : Oxford University Press.

Richardson, Samuel. 1980 (1740). Pamela. Harmondsworth : Penguin

Richardson, Samuel. 1985 (1747-8). Clarissa. Harmondsworth : Viking.

Robinson, A.M. Lewin. 1973. The Letters of Lady Anne Barnard to Henry Dundas. Cape Town : Balkema.

Spacks, Patricia Meyer.1975. Imagining a Self New York : Knopf

Sterne, Laurence. 1960 (1768). A Sentimental Journey. London : Dent.

\section{University of Natal (Durban)}


